マグネシウム之塩酸の量予よび濃度の適量を求め，還元 反応が定量的に進行する条件を設定することが出来た．

（3）検量線の作成

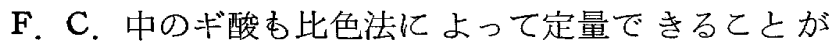
確認された。（限度10\%/ml）

IV 結論

F.C. の上うに大量のホルマリンやクレゾールが共 存している試料からも微量のギ酸を精密に定量する方法 を確立することができた。

\section{4. 日本語子音の波形について}

(九柬大・生理) 友松俊之・涛崎亘三郎 加藤照政・○野代平治

日本語の子音をオシログラフ, ソナグラフ, スペクト ルなどにとって波形や子音の分析を行なった。

てれまでにも知られているように子音は「先行音十後 続母音」という形で単音節を形成している，T (A)，の 先行子音の継続時間は 10〜15msec のごとく短かい. SH (I), S (E) のごときは140〜160msec を要した.

子音の分析にあたって, 先行子音の継続時間, 先行子 音から後続母音への移行部などがどの上うな移行状態を 示すかについて観察の一部を示説したが, 精細なところ は不明な部分が多く今後の研究にまちたい.

\section{5. ムコ多糖類分解醭素剤（塩化リゾチーム製剤）の アフタタ性口内炎に使用せる臨床成繢について}

(九番大・口治) ○山本博武・村成俊彦

消炎酤素剂である塩化リゾチームは Fleming（1922） により卵白の中より分離され，Abraham (1937) により 結晶化されたむので，これらの唾液䤉素は細菌に対して 破壤作用があるといわれ，細菌膜中に存在するムコ多糖 類を分解し消炎作用を呈し，そのほ加抗ウイルス性止血 作用や瘡面の治瘉促進作用などの薬物作用がありへルペ スやアフタ性口内炎に使用されている。狋机は今 回, 塩化リゾチーム製剂（E510）エーザイK．K．の提 供によるものを本学付属病院膿漏部の外来患者で, それ ぞれの症状により内服させ，その臨床成績について報告 をする。

使用薬剂は卫カプセル中に塩化リゾチーム，20mg リ ポフラビン (ビタミン $\left.\mathrm{B}_{2}\right) 3 \mathrm{mg}$ のもので, 通常大人に 1 回上カプセルを1日 3 回食後に内服させた。使用期間 は3 日〜12日間投与させ, その臨床効果を判定した。

1. 弧立性アフタやアフタ性口内炎抢よびロ角ビラン を併発した患者で, その臨床例数は男性 6 例，女性が14
例の20症例であった。

2. 年令別では最高46才，最底年令18才で，その平均 年令は27.5才であった

3. 部位別では上顎 8 例で, 前菌部 5 例, 小曰歯部 2 例，大臼歯部卫例であった。下顎は前歯部 9 例，大曰歯 部 4 例であった。

4. 発生場所別では頓部粘膜が 9 例, 口唇と䢡肉が各 5 例で，口角部が 1例であった。

5.アフタの大ささ, 最小エ×I mmで, 最大 $12 \times 7$ mmであった。

6. その臨床成績は著効 (H) 10 例 (50\%), 有効(H) 7 例 (35\%) で, やや有効（+）1例 (15\%) であった

7. 本症例での副作用は認められなかった。

以上のととから塩化リゾチーム製凨のアフタ性口内炎 の内服は有効であると考えられる。

\section{6. 「新しいF， G，P. 用咬合器, $M M$ 式咬合器に ついて」 \\ (九雨大. 2 霖) 松浦智二 ・ 押方正明 \\ ○岡部泰三}

F. G. P. 用咬合器としては従来より, Jelenko のV ertculator, Hanau のTwinstage Occluder などがある が，以前より松本式第二咬合器が 2 本の平行ロッドによ り，模型を適宜交換できるので，乙れをF，G．P．用咬 合器と代用してきた。 その後 F， G．P. 用咬合器之し て改良を重构，今回一応完成し，MM式峧合器と名付け 発表した。

\section{MM式咬合器の特徽}

1. 松本式第二咬合器の蝶番開閉式に代えて単純な垂 直運動のみとした。

そのために上顎板に 2 個のピンホール，下顎板にそれ と合う 2 本のピンをつけ，な扰 2 個のピンホール上部の ネジ栓にスプリングを取付け，上顎板を押し下げること により下顎板と軽く接触するようにした。 上顎板後部の 固定ネジを締めると，上下顎板が固定され，固定ネジを 緩めると，スプリングの働きで上顎板が直ちに上方に離 れるようになる。

2. 模型取付用の 2 本の平行なロッドは，松本式第二 咬合器と同じであるが, 咬合器が大きくなったので若干 長くした。

3. 可撤歯型式模型 (ダウエルピン使用) でも分割歯 型式模型（ダイロックトレ一使用）であ使用可能であ る。 
4. 局部㐘列模型でも全部歯列模型でも使用可能であ る.

5. 模型取り付け用トレーの使用により，模型の石高 での取り付けが非常に容易となる。

\section{7. 乳歯および永久歯胚を含む下顎骨有形片の即時再 植に関する実験的研究（第1 報）}

（九粎大・1日外）豊 嶋 昭 治

料牙移植の歴史は古く，Greco-Roman 時代に始まる と言われているが，臨床応用がみられるようになったの は20世紀初期からである．1950年 Apfel が㐘根末完成 智菌を同一人の大目歯部に移植し好結果を得て以来,

Langdon \& Young, Fong, 上野, 中村, 平川, 山口ら の追試が報告されている，さらには，顎における各種疾 患による骨欠損に対する骨移植も盛几に行なわれるよう になった。近年，交通事故の頻発による顎一顔西領域の 損傷は急激に增加しつつあり，特に，茵牙および顎骨の 発育途上にある年少者の受傷率は增加の一途を巡るばか りである。そこで，その顎骨内に含まれ将来重要な意義 を持つ永久歯胚の処理方法という重大な問題が起ってき ているので，前述のような末完成幽抢よご米肧あるいは 骨のみの単独移植でなく，私は，乳霜および永久歯脴を 含む顎骨片を即時再植し，その経日的変化を $\mathrm{X}$ 線学的执 よび軟 X線学的ならびに病理組織学的に観祭したので, その概要を報告した。

実験には生後約 3ー5 ケ月の健康雑種幼犬を用い，右 側下顎第 3 乳歯尔よび永久第 4 小曰歯歯胚を含九顎骨片 を採取し，一年時間抗生剂加生理的食塩水に浸漬した 後，同部に再植を行なった。な扔，対照群として非実験 側である左側下顎骨を用いた。

$\mathbf{X}$ 線学的および軟 $\mathbf{X}$ 線学的には, 時日の経過と共に乳 歯柬根扝よび蒾肧の吸収傾向がみられるが，再植接合部 は透過度を次第に減じ骨癒着の増進が推察できる。

病理組織学的には, 乳歯执よび蒾肧ならびに顎骨に退 行性変化がみられたが, Host よりの新生骨梁の増生は 再植後 7 日目以降において次第に増大し，その䉇团を増 している。

今回の報告においてはまだ例数も少なく，今後，圆定 方法になお一層の検討を加え，例数を増やすと共に長期 間にわたる観察を行なって，後日詳くし報告するつもり である。

\section{8. 口腔領域に発生した畽痬組織の神経線維分布に関 する研究 (予報)}

\author{
(九霜大・1口外) 巨山 保・ $\bigcirc$ 小山 䉷
}

各組織の神経分布あるいは種 々の実験後の神 経の変 性，再生についての研究は諸家によって追筧され，次第 に明らかとなりりつつある。しかるに，今日，腫㴼，特 に悪性腫湯に関する研劣は多種多様を極め，あらゆる的 度加ら究明されているにもかかわらず，神経分布に関す る報告は，私達の調查した範囲ではみあたらないようで ある。したがって，私達は，口腔領域に発生した腫湯の 神経分布について観察しているので，今回は，その一部 の悪性腫湯について，次のような所見をみたので報告し た。

観察方法ならびに材料：口腔領域に発生した扁平上皮 癌抢よび単純癌数例を鍍銀染色にて観察した。

所見：1、神経束あるいは比較的太心神経線維は，腫 汮と健康組織との移行部付近に多くみられた。

2.腫痬の䦭質中に存在する血管に神経線維が随伴し ていることが多い。

3.腫瘍実質が, 神経線維を国繞するように浸潤して いる所見むみられた。

\section{9. 下顎骨連続離断後の骨再生に関する研究} （第 3 報）

（九菡大·1口外) 木 村 卓 生

近年スポーツの普及，交通事情の複雑化に伴い，外傷 による重篤な欠損骨折などにしばしば遭遇し，また良 性, 覀性の腫晹により䫈骨の連続離断を余儀なくされる 症例屯少くはない，乙のような骨久損部に対する処置と しては，一般に自家骨の移植によりその機能の回復がは かられている。しかしながら，若年者の場合において移 植骨の採取に困難をきたす事がある，筒移植によらない 骨の修復に関しては1962年 Hinds，1966年 Brady らは $1 \mathrm{~cm}$ 以内の骨欠損に刘し骨移植を行なわないで 3 ケ月 間の固定で骨連続ができたととを報告している．また 1969年 Raymond は成犬を使用し，メタル・プレートと スクリユウドライバーにより固定し，１ cm の骨欠損は 3 ケ月， $1 \mathrm{~cm}$ 以上 $1.8 \mathrm{~cm}$ 以内の骨众損では 4 ケ月で骨 連続をみたと実験的に報告している。

私は幼若犬において下顎骨連続離断術をおこない，骨 膜保存群亡骨膜除去群の治療過程について比連钼察を扔 こない，咋年の本学会に扔いて報告した。

その後，さらに成犬に拉いて同様な実験を追加し，奻 若犬上成犬との治療過程を比較検討を加えたので報告す 